\title{
USE OF SOLAR ENERGY FOR HEATING MEAL AT EDUCATIONAL CENTERS
}

\author{
Shyam S. Nandwani ${ }^{1} ه$ (iD) \\ ${ }^{1}$ Retired Professor, Universidad Nacional, Heredia, Costa Rica, Independent Researcher, User and Promotor \\ of Solar Energy, Heredia, Costa Rica (Central America)
}
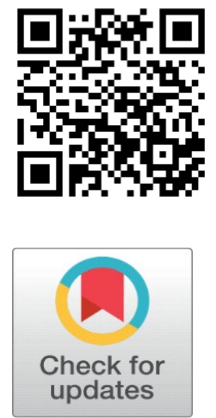

Received 17 December 2021

Accepted 30 January 2022

Published 17 February 2022

\section{CorrespondingAuthor}

Shyam S. Nandwani, snandwan@yahoo.com

DOI 10.29121/ijetmr.v9.i2.2022.1108

Funding: This research received no specific grant from any funding agency in the public, commercial, or not-for-profit sectors.

Copyright: (C) 2022 The Author(s). This is an open access article distributed under the terms of the Creative Commons Attribution License, which permits unrestricted use, distribution, and reproduction in any medium, provided the original author and source are credited.

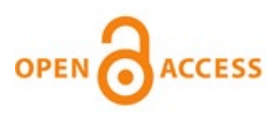

\section{ABSTRACT}

Warming meal at educational centers for students is done with microwave ovens consuming high energy and making long queue. Conventional hot box solar ovens can warm meal using free, abundant, and clean Solar energy, during 10-11 months in a year in many places in Costa Rica. For the rest of the periods, if heating is required one can use Microwave Ovens. Different types of pots which can be used both in Solar and Microwave ovens have been searched and are studied. Due to pandemic period experiments have been done at authors house for measuring oven, meal temperature with solar radiation and with different pots. The heating of 14 lunch boxes is done with one solar oven and even simulating the clouds to see the performance and results are very promising. Due to COVID during 2020 and 2021, the classes were virtual, thus the real heating could not be done in any college to see the acceptance by the students and staff. We plan to promote see the real performance during 2022 .

Keywords: Different Solar Ovens, Solar Ovens Meal Heating, Microwave Meal Heating, Pots for Solar Ovens, Plastics for Clouds

\section{INTRODUCTION: USE OF MICROWAVE OVENS FOR HEATING MEAL}

Everyone has to take hot lunch $\left(40-50{ }^{\circ} \mathrm{C}\right)$ during mid-day. Although I will talk of warming meal at educational centers, the study can be applied also to warming lunch at offices, houses and even street vendors.

Most of the students take their meal from home and heat in Microwave (MW) ovens, basically because of convenient and short time to heat meal. Regarding pots, its well-known that any pot can be used except metallic or even with metallic lining, thus almost everyone uses plastic pot, some good, some medium and some even worst plastic pot. No doubt this is convenient and fast way to warm lunch box. However, there are some limitations like:

1) Heating each lunch box requires 2-4 minutes, depending on the quantity of food, material of lunch box and the power of MW oven. Just for heating 200 pots per day only in one college (secondary school), using 3 minutes with $1 \mathrm{~kW}$ Microwave oven, for 200 days will be $2000 \mathrm{kWh}$ of electrical energy or US\$330/ per year. Thus, electric energy consumption for many institutions may be high. In a country with population of 5 million, there are about 1,000,000 students in schools and colleges, consuming lot of electricity for heating meal. 
2) In MW oven, one meal can be heated at a time. For students' long queue and more time is needed to heat meal for say 100-200 students. Their lunch break is only 30-45 min. Some colleges even have even 5-10 Microwave ovens. Even then not always all the students can heat lunch during this time so some may have to take cold meal.

3) During 20 years, visiting many schools and colleges, I have observed that not all the MW pots used for warming are suitable for Microwave oven. Melting of some plastic boxes can take place if they are not appropriate for MW.

4) Some families do not prefer microwave ovens for possible health problem, like cancer. Its debatable issue, as its not confirmed explicitly.

5) Although 99 percent of country is connected with electric grid however still about 200 schools and colleges do not have electricity, thus they cannot use Microwave ovens

Thus, another option could be the use of solar energy for heating the lunch.

\section{USE OF SOLAR ENERGY FOR WARMING AND COOKING}

Author made first time solar oven for personal use at home in Costa Rica in March 1979 for warming personal family lunch in Costa Rica, as shown in Figure 1, which was published in local newspaper Nandwani (1979). The reason was due to electric rationing imposed by National public electric utility company for 2 days a week from 7 am to $7 \mathrm{pm}$. It was because of reduction of water level in hydro dams due to sunny period.
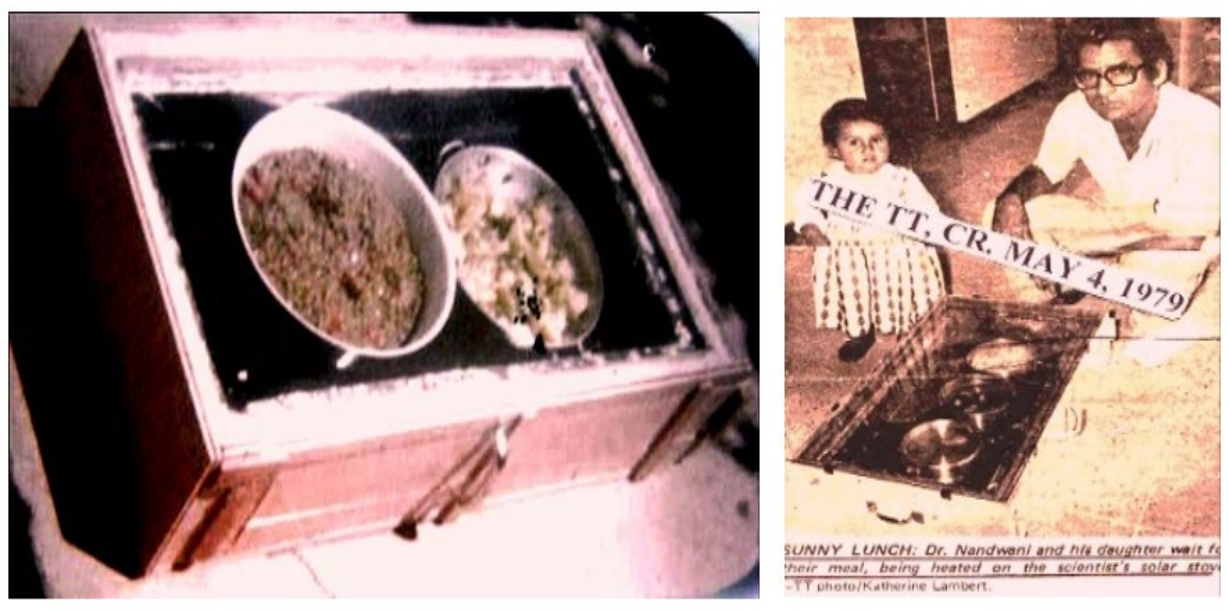

Figure 1 Our first Solar Food warmer (Left) for the house in March 1979 and published in local newspaper (Right)

Although author has designed, studied, and published many solar ovens for cooking, like Conventional Oven Nandwani (1988), Hybrid solar oven Nandwani (1989), Solar Microwave Oven Currin et al. (1994), Multipurpose and partial heat storage solar oven Nandwani et al. (1997), Dual voltage solar oven Nandwani (2008). All these models can be seen in authors book Nandwani (1993-2003) and extensive article in Encyclopedia of Sustainability Nandwani (2012-2021), The conventional Solar Oven in brief consists of wooden/metal box, with metal plate painted black on top, glass wool as thermal insulation on four sides and below the metal plate. On the top of the box, there are two transparent glasses, separated by 
$2-3 \mathrm{~cm}$ to allow the solar radiation to enter but impedes the exit of heat radiation Nandwani (2021).

Also, there is one reflector, whose angle could be adjusted to receive additional solar radiation. Author also got patent on Solar Oven in Costa Rica in 1984. Meals can be cooked in 90-150 minutes depending on the climate, quantity of meal and types of cooking boxes, however for heating meal, it takes much less energy and thus less time. Cooked meals can be reheated in 30-90 minutes. In the case of educational centers for warming meals, the size of the of absorbing plate could be about $100 \mathrm{cmX60} \mathrm{cm}$ or $0.6 \mathrm{~m}^{2}$ Nandwani (2014). This oven can accommodate about 4050 lunch boxes (in two layers). In order to minimize the risk for students, we recommend not to use reflector, especially in windy areas.

On a sunny day the maximum air temperature in the oven can reach up to 120$140{ }^{\circ} \mathrm{C}$ (without meal), more than sufficient to cook meal and about $90-110{ }^{\circ} \mathrm{C}$ with meal inside. One can cook meal for about 6-9 months and can heat lunch for about 9-11 months in a year depending on the place/climate. In addition, I am cooking/warming meal at home for last 40 years and also promoting the use of Solar Ovens at educational institutes for last 15 years Nandwani (2021), through lectures and workshops. Some students in my university were using solar ovens to heat their lunch.

Being from developing country (India) and working in developing country (Costa Rica) and given lectures in many developing countries, I think it's very necessary to use Solar Energy also for heating food. At home most of the time the meal is cooked for 2-3 days and sometimes one has to only heat the cooked breakfast and lunch. Burning firewood stove or switching electric/gas range, its much simpler to use simple solar oven to warm. Three to Four meals can be heated simultaneously even on partial sunny period.

Although about 20 articles are published by author only on Solar Ovens since 1979, however in this papers new practical and unpublished results before, are informed which are studied during pandemic years 2020 and 2021.

\section{USE OF POTS FOR SOLAR OVENS}

Regarding the pots, normally in solar ovens we use metallic pots because of good thermal conductivity. However due to drastic climate change or some students forgot to keep the lunch in Solar oven, one has to use Microwave oven for warming meal. As the metallic pots cannot be put in microwave oven, thus we recommend thermal plastic pots $\left(-20\right.$ to $\left.+120^{\circ} \mathrm{C}\right)$ which can be used in both solar ovens as well in Microwave ovens. Figure 2 show some plastic pots bought at different places/countries and at different times which can be used also in microwave ovens and satisfy other conditions like convenient size and weight etc. Pot G, bought in 2019 from Delhi/ India, is of stainless-steel inside plastic pot. Claimed by the manufacturer, it can be used also in microwave oven and rechecked by author. 

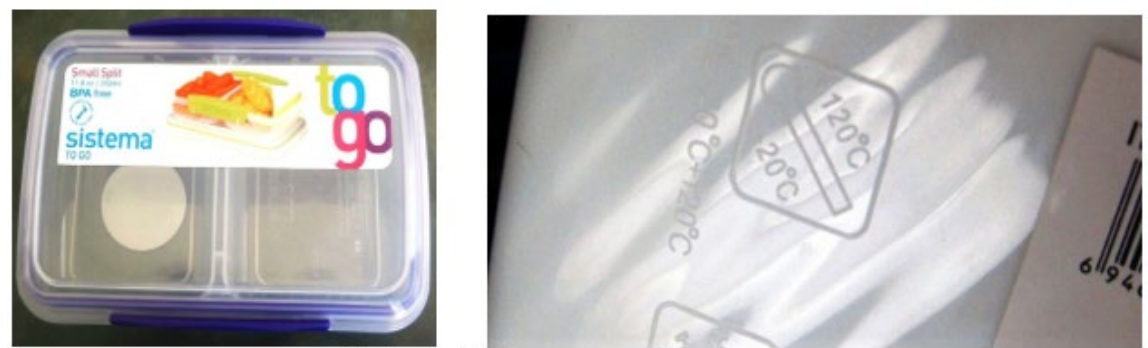

A. Thermal Transparent plastic pot
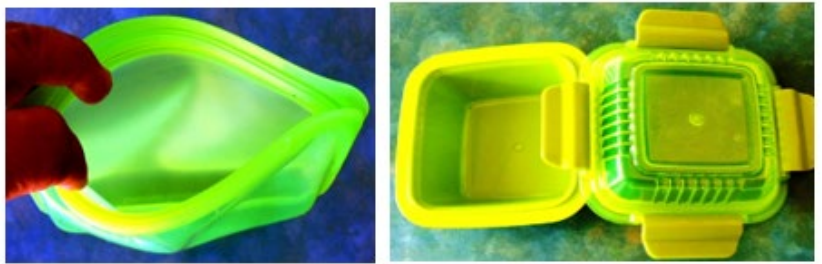

B. Silicon Transparent Bag.

C: Double Green Transparent Plastic Pot

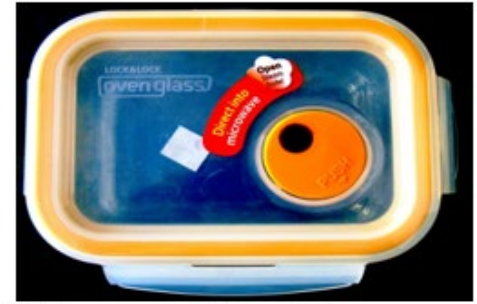

D. Transparent Glass Pot

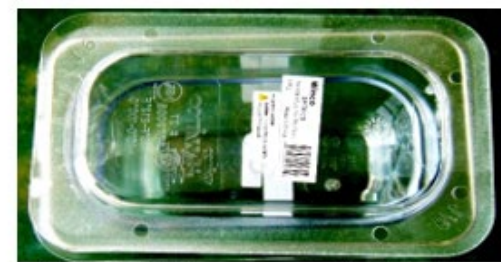

F. WinCo Transparent Plastic Pot

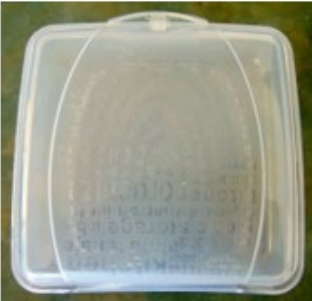

E. Transparent Plastic Kitchen Pot

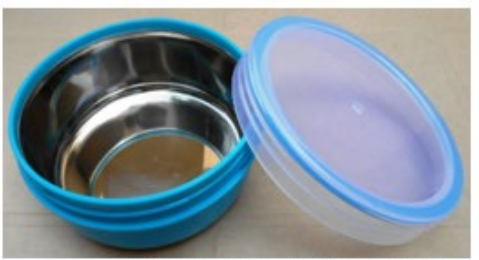

G. Indian Plastic/ Steel Pot

Figure 2 Different types of thermal Plastic pots studied for warming lunch in solar and microwave ovens

\section{HEATING OF 14 LUNCH BOXES WITH SOLAR OVEN}

Although we know the temperature attained in the domestic oven (3-4 cooking pots) at our house, but never measured temperature variation at school/college where the students heat about 40-50 lunch boxes simultaneously in one oven with sunny period as well cloudy period. Although students and Directors of colleges are satisfied with the performance of solar ovens.

As the real experiment cannot be done for heating many lunch boxes in Solar oven, a

$\mathrm{s}$ is done at some colleges due to different reasons. I thought of heating 14 lunch boxes at personal house (Figure 3). The solar oven used has an absorbing plate of the size, $52 \mathrm{~cm} . X 34 \mathrm{~cm} \mathrm{X} 16 \mathrm{~cm}$. (absorbing area of $0.17 \mathrm{~m}^{2}$ ) and without reflector. Although we could calculate this rise in temperature theoretically with different solar intensity, however experimental data may convince better to possible users and promoters. All the pots were of thermal plastic. Did experiment with natural and reduced (simulating clouds) solar intensity with some covers. 


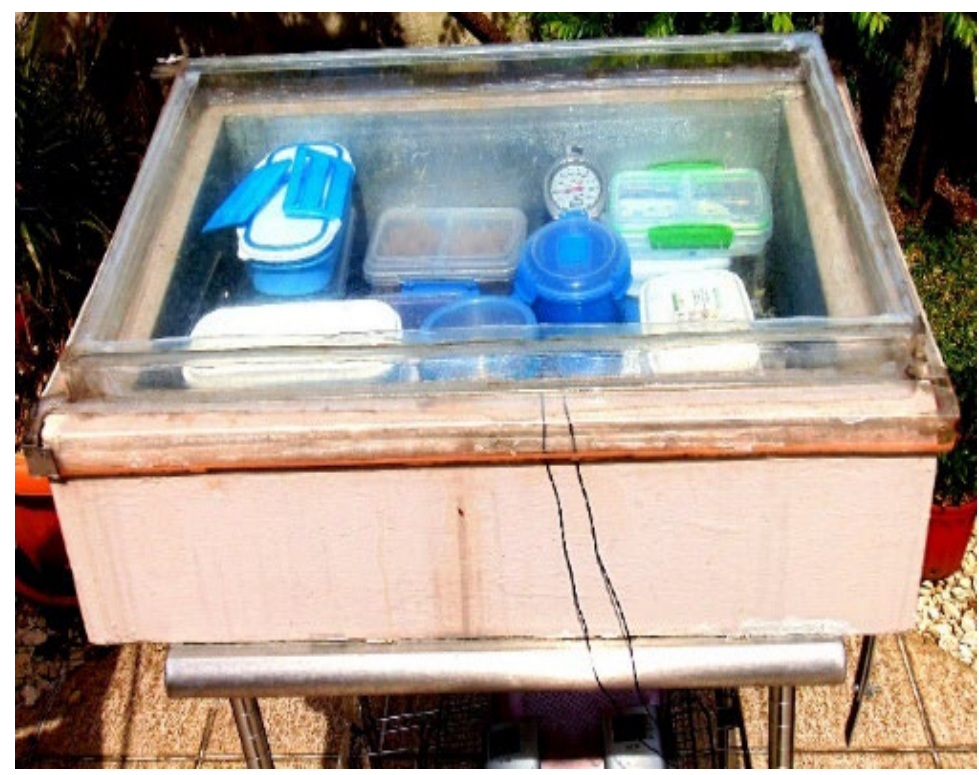

Figure 3 Heating of 14 lunch boxes with pinto to heat with solar energy

Fourteen 14 boxes (average size, $17 \mathrm{~cm} \mathrm{X} 11 \mathrm{~cm} \mathrm{X} 4 \mathrm{~cm}$ ) were used for individual meal. We put 12 boxes with $250 \mathrm{~g}$ of water and two boxes with $250 \mathrm{~g}$ pinto (typical Costa Rican dish, rice, beans, spices etc.) each, in two layers. Total weight of pinto in 14 boxes is $3.5 \mathrm{~kg}$. These two pots also had thermometer to measure pinto temperature.

Experiments were done on 10,12, and 13 March 2021. Results are presented only for two days. In schools, some persons in charge, keep all the lunch boxes at the same time, 2-3 hrs. before lunch time. In colleges and universities students keep their lunch box at different times, depending on their convenience. Thus, we have done experiments with two ways of keeping meals- keeping all the lunch boxes at the same time (like schools) and keeping half boxes first (lower layer) and then rest of the boxes, 60-90 minutes later at upper layer (as in colleges).

4A. March 10, 2021: From 8:30 to 9:30 am no boxes were kept, oven was just getting (accumulating) solar energy. At 9:30 am, all the 14 lunch boxes including two pinto boxes were kept in two layers, in solar oven. The temperature of pinto in two pots, (one in top layer and other in bottom layer/line) and in solar oven and solar radiation were measured. Ambient temperature during this period was varying between $25-31{ }^{\circ} \mathrm{C}$. From 9 to $12 \mathrm{md}$ the oven was not moved as students attending the class would not do it. The results are shown in Figure 4A. The oven temperature was between $80-90{ }^{\circ} \mathrm{C}$. 


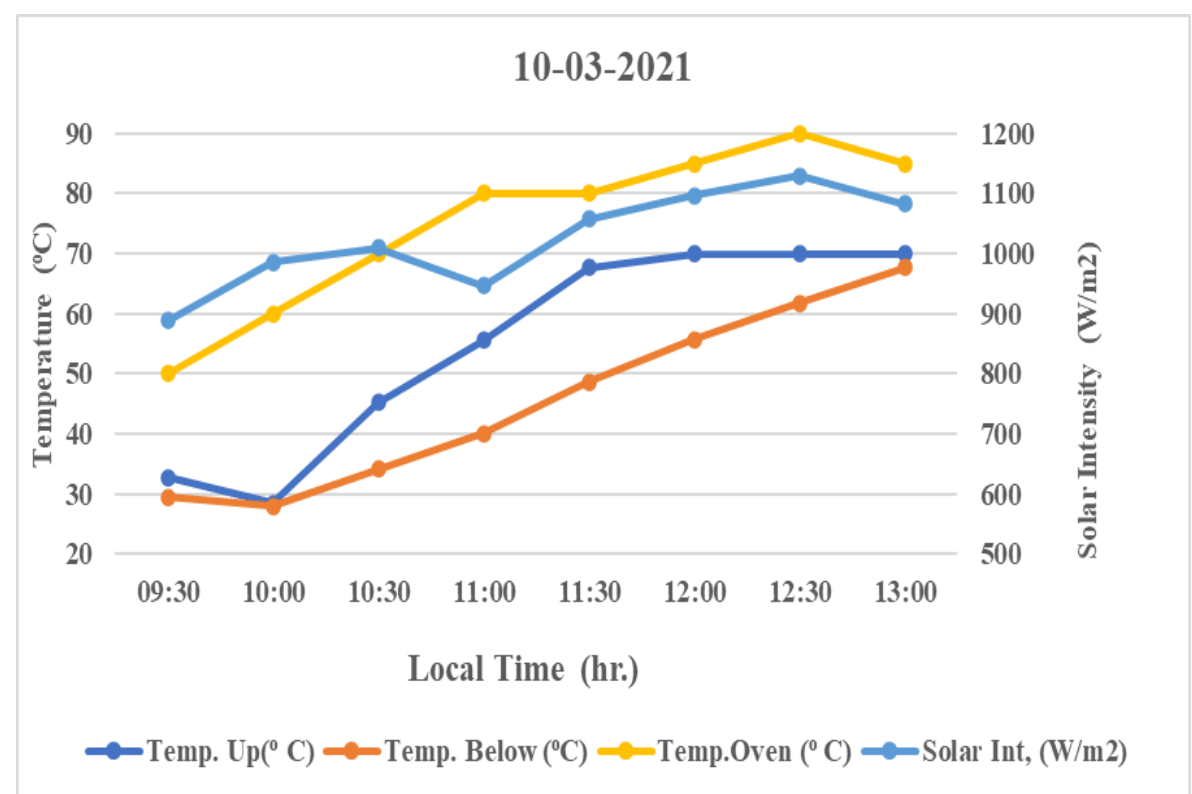

Figure 4A. Variation of pinto temperature in upper and lower lunch box at different times with solar radiation, March 10, 2021

4B. March 13, 2021: The day was sunny. During 8 to 9 am, no pots were kept, although oven was receiving/ accumulating solar radiation. At 9 am 6 water boxes ( $250 \mathrm{~g}$ in each pot) and one pinto box were kept. At 10 am another 6 water pots and one pinto box were kept on top of these 7 boxes (as in colleges). One temperature sensor was put in each pinto box (one in each layer). The pinto temperature in upper and lower pots, oven air temperature and solar intensity are shown in Figure 4B. Even for boxes kept after one-hour, pinto temperature reached to $55-58{ }^{0}$, more than sufficient to enjoy hot lunch.

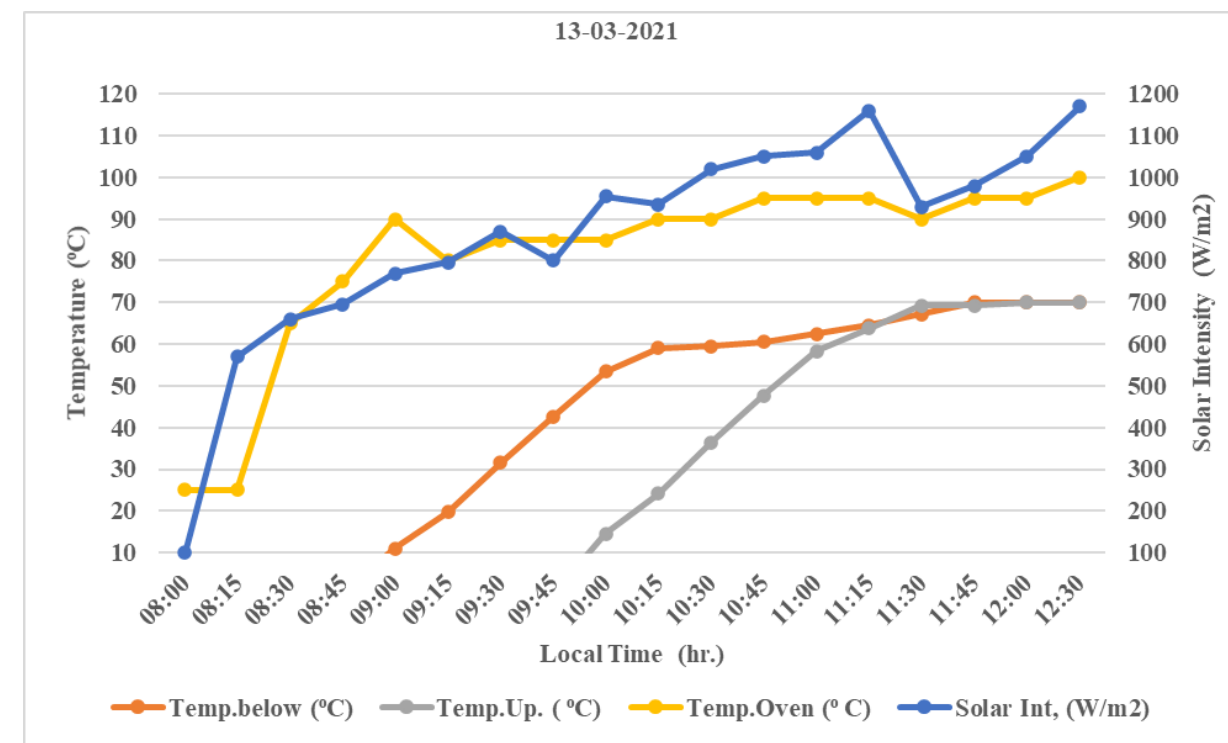

Figure 4B. Variation of pinto temperature in upper and lower lunch box at different times with solar radiation, March 13, 2021 


\section{REDUCING SOLAR INTENTITY, CREATING/SIMULATING CLOUDS}

During more than hundred lectures given at educational centers and at other places, most of the people ask obvious question, what happens during cloudy period. Thus, we decided to make some measurements during different cloudy period. To make an artificial cloudy period, I thought to use some plastics/cloth of different thickness with different transmission/shade and did similar experiments as above. To have some quantitative results, we also measured the transmissivities of these materials.

Two plastics (Number 2 and number 3) and one cloth (number 4) of different thickness were bought and using solar radiation meter (Figure 5), their individual and combined (like 2 and 3, 2 and 4 etc.) transmissivity was measured, by measuring the solar radiation above and below the transparent materials. Although different measurements were made, but average data are shown in Table 1.

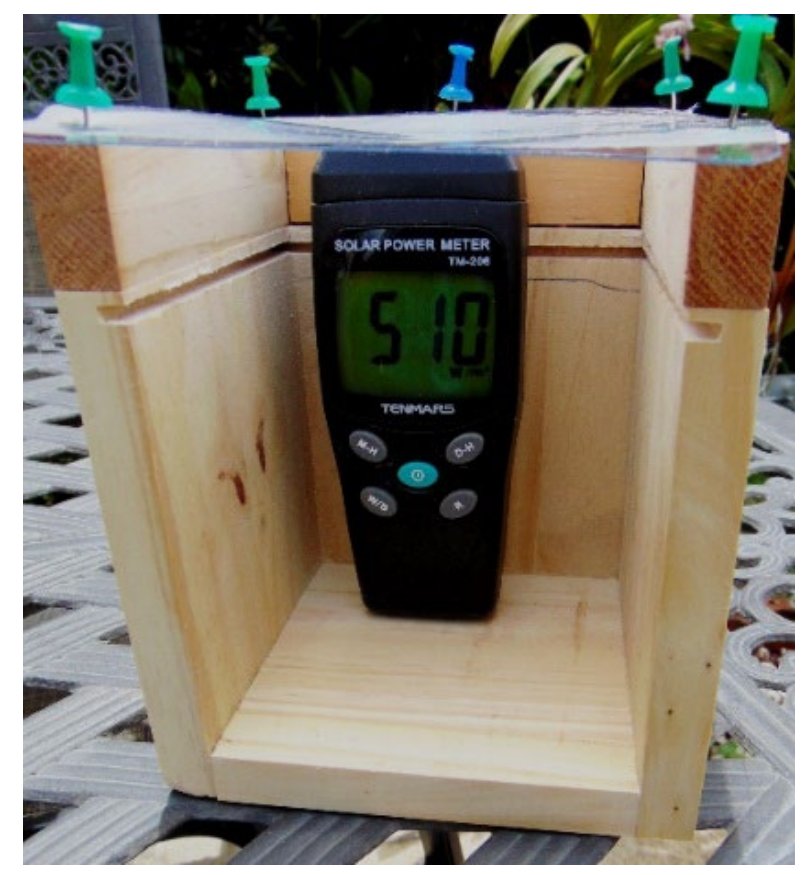

Figure 5 Box for Transmission measurements of different materials

\begin{tabular}{|cccc|}
\hline \multicolumn{4}{|c|}{ Table $\mathbf{1}$ Transmissivity of $\mathbf{3}$ Transparent Materials } \\
\hline Material & Solar Intensity (W/m2) & Transmission Coefficient \\
\hline & ABOVE & BELOW & \\
\hline 2 & 1040 & 970 & 0.93 \\
\hline 3 & 1110 & 980 & 0.88 \\
\hline 4 & 965 & 650 & 0.67 \\
\hline 2 and 3 & 1082 & 875 & 0.81 \\
\hline 2 and 4 & 1130 & 675 & 0.6 \\
\hline
\end{tabular}


Although we also measured the transmissivity of three materials together $(2,3$ and 4), it came out around 38\%, (very low transmissivity or more clouds) thus we did not measure the thermal performance of solar oven for heating meal.

\section{HEATING OF 14 LUNCH BOXES WITH SOME SHADE}

Similar to previous experiments, the measurements are repeated with 14 pots ( 2 with pinto and 12 with water), each having $250 \mathrm{~g}$, but adding some plastics on top of the solar oven to create shade/cloud. Wooden frames were made for fixing different plastics. In all the experiments from 8 to 9 am no meal boxes were put in the solar oven; it was just to heat the oven. At $9 \mathrm{am}, 14$ lunch boxes were put in two layers. Meal/ water, oven temperature, solar radiation over solar oven with and without cover were measured (Figure 6).
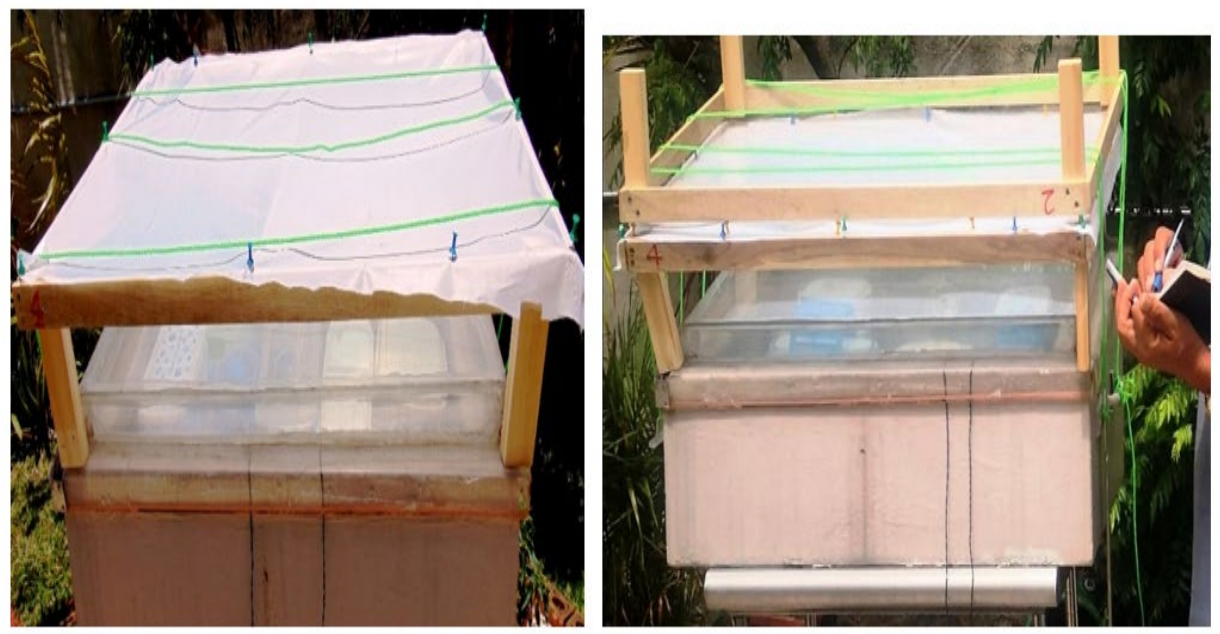

Figure 6 Thermal performance of Solar Oven for warming 14 lunch boxes with clouds

The oven was set only once at 9 am, then it was not moved until $1 \mathrm{pm}$. Experiments were done on April 2, 4, 6 and 8, 2021, we will give some results.

\section{A. Experiment with Cover No. 4 (Cloth), April 2, 2021}

At 9 am oven temperature was already $70{ }^{\circ} \mathrm{C}$. At 9 am one lunch box with pinto and 6 with water were put in lower layer. One temperature sensor was put in pinto box (TpD). Frame with cloth no. 4 was used as cover. At 10:30 am, put another 7 boxes, including one pinto box with temperature sensor (TpU).

Temperature in two pots, in oven, solar radiation was measured under the frame with cover, each $15 \mathrm{~min}$. The ambient temperature was varying between 24$29{ }^{\circ} \mathrm{C}$. The results are shown in Figure $6 \mathrm{~A}$. 


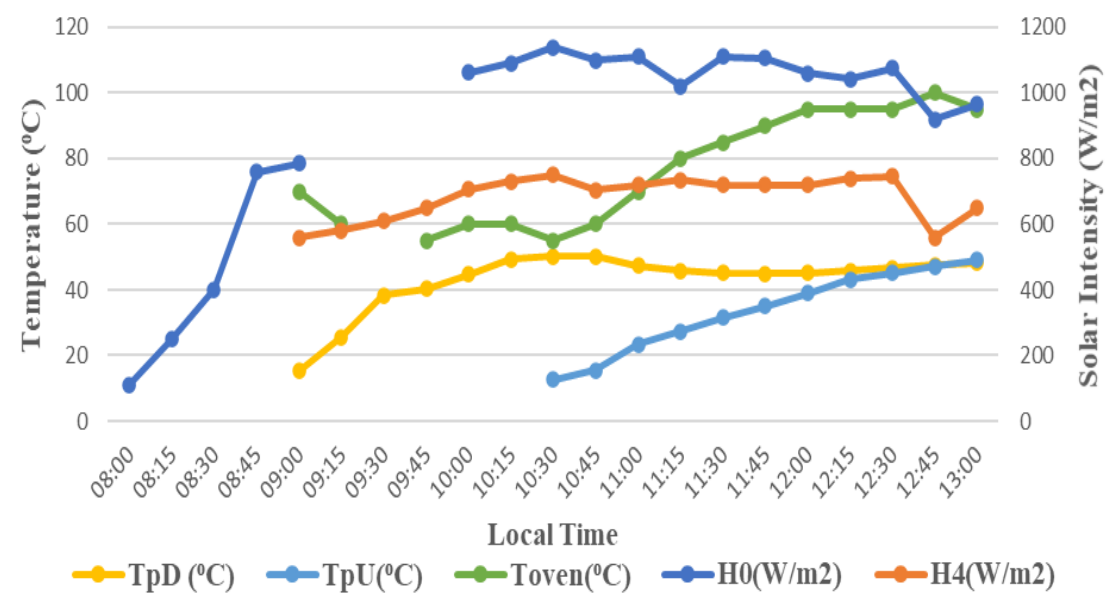

Figure 6A. Variation of pinto temperature in upper and lower lunch box at different times with solar radiation and partial clouds, April 2, 2021

Even with solar intensity reduced by $30 \%$. The maximum pinto temperature was $45^{\circ} \mathrm{C}$ and $39{ }^{\circ} \mathrm{C}$ in lower and upper box at lunch time (12 md) sufficient hot to enjoy and $48-49^{\circ} \mathrm{C}$, at $1 \mathrm{pm}$, The oven temperature was varying between $50-100{ }^{\circ} \mathrm{C}$. The day was sunny but was made cloudy. In summary,

Transmissivity of cover, $67 \%$.

Oven Temperature before keeping lunch boxes ( 8 to $9 \mathrm{am}) 70{ }^{\circ} \mathrm{C}$.

Temperature of Pinto in lower layer at $12 \mathrm{md}(9-12 \mathrm{md}) \quad 45.2{ }^{\circ} \mathrm{C}$

Temperature of Pinto in upper layer at $12 \mathrm{md}(10: 30-12 \mathrm{md}) 39.1{ }^{\circ} \mathrm{C}$

Oven temperature was varying between $55-100{ }^{\circ} \mathrm{C}$.

\section{B. Experiment with Cover No. 4 (Cloth), April 4, 2021}

Experiment was repeated on April 4. Oven was heated from 8 to 9:30 am, without any meal. Oven temperature (without meal) reached to $100{ }^{\circ} \mathrm{C}$. At 9:30 am 7 boxes (one cooked pinto meal and 6 water) were put in solar oven; one temperature sensor was put in pinto box. The oven was covered with plastic/cloth 4 (transmissivity 67\%). At 11 am put another 7 boxes in the upper layer (simulating college students), with one temperature sensor in pinto box.

The measured pinto temperature, solar radiation and oven temperature variation are shown in Figure 6B.

In summary,

Temperature of pinto in lower box at $12 \mathrm{md}(9: 30-12 \mathrm{md})$ is $51.4{ }^{\circ} \mathrm{C}$

Temperature of Pinto in upper box at $12 \mathrm{md}(11-12 \mathrm{md})$ is $45.4{ }^{\circ} \mathrm{C}$

Oven temperature was varying between $55-100{ }^{\circ} \mathrm{C}$. Although day was sunny, again we made it partially cloudy with an extra cover. 


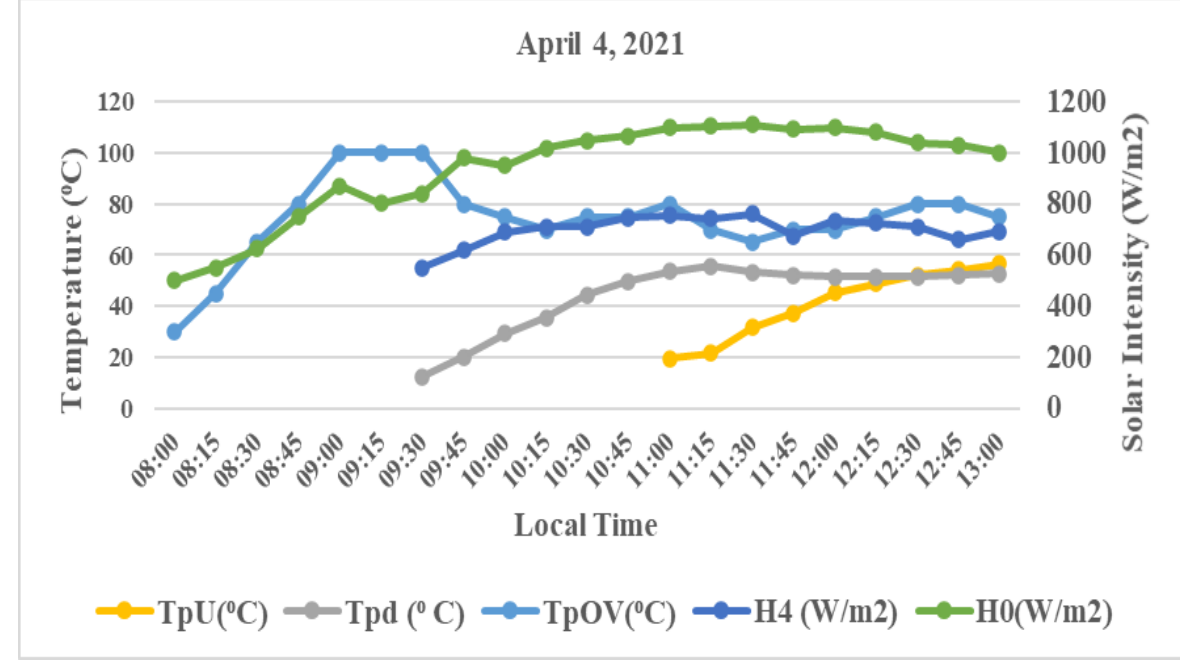

Figure 6B. Variation of pinto temperature in upper and lower lunch box at different times with solar radiation with partial clouds, April 4, 2021

\section{C. Experiment with Cover No. 2 and 4. April 6, 2021}

In order to reduce some more solar intensity (or increase clouds), we used two covers. Although the order is not important, we put plastic no 2 on top of cloth no 4. At 9 am oven temperature, without any meal reached to $95{ }^{\circ} \mathrm{C}$ (from $25{ }^{\circ} \mathrm{C}$ at $8 \mathrm{am}$ ). In this case all the 14 pots were kept in two layers, having one temperature sensor in pinto (lower layer, Tpd) and another sensor in pinto in upper layer (TpU). It was sunny day, reduced intensity by $39 \%$ due to two sheets. The oven (TpOV) and Solar intensity above plastic (H0) and under two plastics (H24) are shown in Figure 6C.

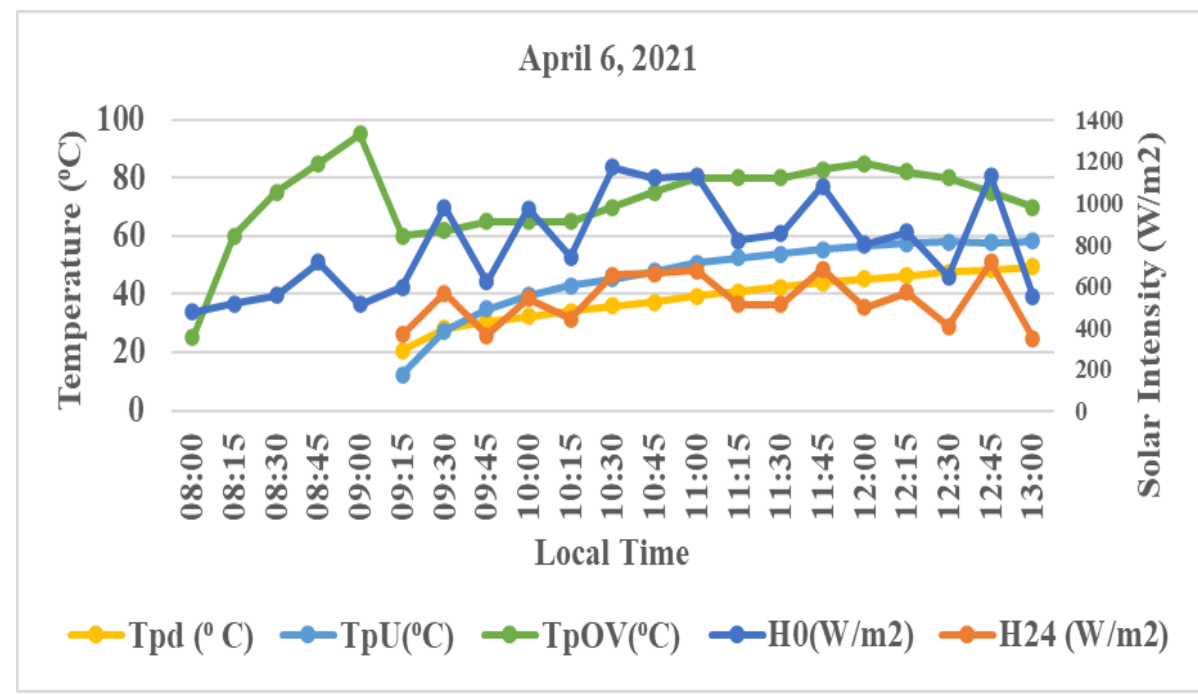

Figure 6C. Variation of pinto temperature in upper and lower lunch box at different times with solar radiation with partial clouds, April 6, 2021

Temperature of pinto in lower layer at $12 \mathrm{md}(9-12 \mathrm{md})$

$45.2{ }^{\circ} \mathrm{C}$

Temperature of pinto in upper layer at $12 \mathrm{md}(9-12 \mathrm{md})$

$56.7^{\circ} \mathrm{C}$ 
Ambient temperature was varying between $28-32{ }^{\circ} \mathrm{C}$. Oven temperature was varying between $60-85{ }^{\circ} \mathrm{C}$.

\section{COST OF SOLAR OVEN AND PERIOD OF AMORTIZATION}

One metallic solar oven for about 50 lunch boxes. which can be kept in sun/rain, can cost about Colone's 250,000 (US\$350-400). Also based on long experience we know Solar Oven can be used for 11 months in a year for heating. Let us calculate period for recovering the initial cost, through use of solar energy. We will compare with electrical energy required to heat the same meal in Microwave oven, as it is done normally in educational institutes or many offices.

Assuming heating of each lunch box in a Microwave oven (power about $1 \mathrm{~kW}$ ), takes 3 min.

Electric energy required to heat 50 lunch boxes for 11 months will be: $50 \times 1$

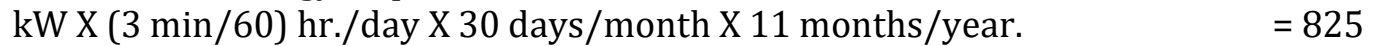
$\mathrm{kWh} /$ year

Electricity cost in Costa Rica is about $\$ 0.14 / \mathrm{kWh}$. Money saved will be $=$ $\$ 115 /$ year. thus, the initial cost can be recovered in 3-4 years. Also, this metallic solar oven has a life of at least 10 years, although this author is using one at home for last 20 years.

\section{ADVANTAGES/LIMITATIONS OF SOLAR OVENS}

In addition, Solar Oven can be used even for heating water, pasteurizing water, drying some agricultural products like spices, herbs, for realizing some science experiments by students and baking cake for some party etc. Although it takes some more time but has many other advantages-economic, environmental Nandwani (1996), nutritional and convenience like heating many meals simultaneously etc.

Figure 7 shows one solar oven, installed at one college for heating meal to save electric energy for college and convenience for students (both warming lunch and studying simultaneously) and also for cooling the earth etc.

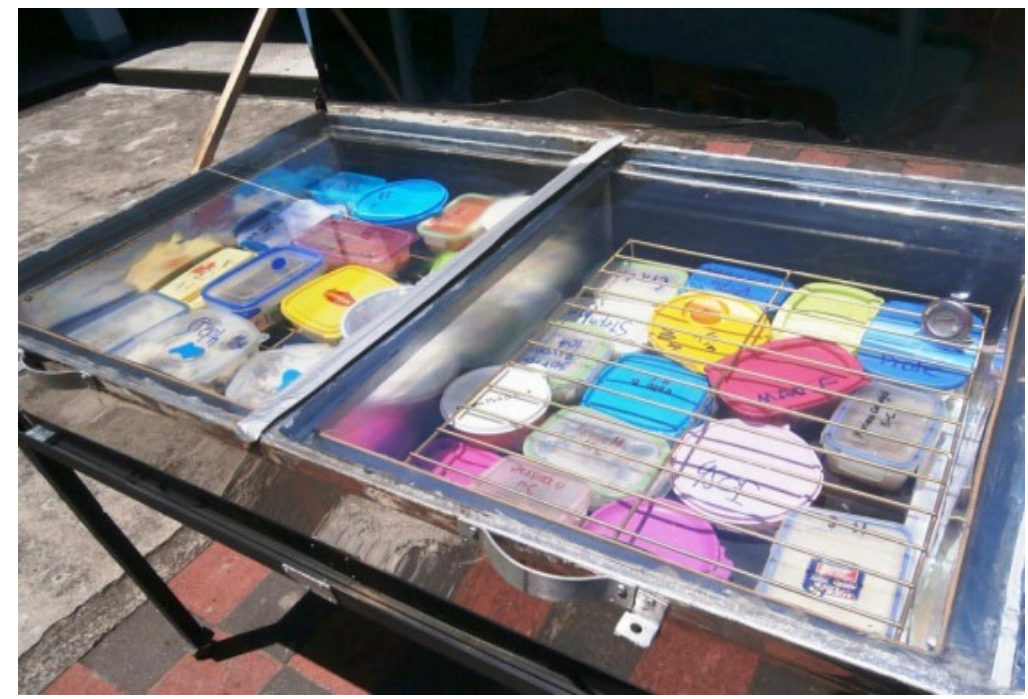

Figure 7 Solar ovens at Colegio Maria Auxiliadora, San Jose, lunch boxes in two layers 
In spite of many advantages, including short period de amortization, only 3040 educational institutes have installed about 80-90 solar ovens. Possible reasons could be lack of proper space, playground nearby, adverse effect due to wind especially in summer and more important is comparatively high initial cost of Solar Oven. One metallic Solar oven of the size, $100 \mathrm{~cm} \mathrm{X} 60 \mathrm{~cm}$, for heating 40-50 lunch boxes, in about 2-3 hrs. can cost around Colon US $\$ 350-400$, about $3-4$ times the cost of single Microwave oven.

First two limitations can be solved in some cases finding another place for keeping solar ovens and buying good insulating bag. Regarding third limitation, oven has some higher initial cost. The reason of comparatively high cost is because as there are no full-time sellers, some sellers make on demand and very low numbers. Many persons specially in developing countries may not go for solar oven due to some higher initial investment even the saving is recovered in short period.

The other options for cost reduction for heating meal could be:

1) Wooden or even Cardboard oven,

2) Portable and personalized solar oven and

3) Heating meal directly in pots with solar energy but without solar oven.

To reduce the cost of heating meal with solar energy but without expensive solar oven has been studied also recently and will be presented in another paper.

\section{CONCLUSIONS}

The study was done with different plastic pots, which could be suitable for both solar and microwave ovens. We did detailed study with solar energy and simulated cloudy period for heating about $4 \mathrm{~kg}$ of cooked meal kept in 14 lunch boxes, all with $250 \mathrm{~g}$ of pinto and the results are very promising.

Due to pandemic situation, now a days the classes are virtual. Once this situation gets normal and classes are presential, planned in mid-February 2022, we can see the acceptance by students and public etc. We expect that this study for heating meal with solar energy can be used by more educational and other institutions.

In addition to saving conventional fuels, it will also help in cooling the planet. In conclusion one may say that most of the time simplest solution is the best solution.

\section{REFERENCES}

Ced Currin, S.Nandwani, M.Alpizar (1994), Preliminary Study of Solar Powered Microwave Oven, in Proceedings of Second World Conference on Solar Cookers Use \& Technology, Costa Rica. Edited by S. Nandwani, Bev Blum and E.Pejack.

Shyam S. Nandwani (1989), Design, Construction and Experimental Study Electric Cum Solar Oven, Solar and Wind Technology. 6, 149. Retrieved from https://doi.org/10.1016/0741-983X(89)90024-6

Shyam S. Nandwani (2008), Design, construction and study of hybrid and dual voltage Solar cooker in the climate of Costa Rica, Renewable Energy, London, UK, 103. 
Shyam S. Nandwani (1988), Experimental and Theoretical analysis of simple solar oven in the climate of Costa Rica I, Solar and Wind Technology. 5, 159. Retrieved from https://doi.org/10.1016/0741-983X(88)90075-6

Shyam S. Nandwani, J. Steinfart, H.Henning, M. Rommel, V. Wittwer (1997), Experimental Study of Multipurpose Solar Hot Box at Freiburg Germany,Renewable Energy, Int. Journal, 12, 1. Retrieved from https://doi.org/10.1016/S0960-1481(97)00014-1

Shyam S. Nandwani (1996), Solar Cookers Cheap technology with high ecological benefits, Ecological Economics, 17,73. Retrieved from https://doi.org/10.1016/0921-8009(96)00021-3

Shyam S. Nandwani (2021), Solar Ovens - for Cooking food and cooling the earth, Appropriate Technology. England, 2, 48.

Shyam S. Nandwani (2014), Solar cookers for Educational Centres in Costa Rica, World Conference on Solar Cooking, Solar Cookers International, Sacramento, USA. Retrieved from https://youtube.com/watch?v=Bw6mGqw-tEV

Shyam S. Nandwani (1979), Sunny Visións- Getting a Charge from Old SUN, The Tico Times, Costa Rican English Newspaper,, May 4, 21

Shyam S. Nandwani (1993-2003), Book, La Cocina/ Horno Solar, Hagala Usted mismo, (Fundación, Universidad Nacional, Costa, Rica), 125.

Shyam. S. Nandwani (2012-2021), Solar Cookers and Dryers to conserve Human and Planet Health, Encyclopedia of Sustainability Science and Technology, Edited by R. Meyers, Springer Verlag. 